Available online at GSC Online Press Directory

GSC Advanced Research and Reviews e-ISSN: 2582-4597, CODEN (USA): GARRC2

Journal homepage: https://www.gsconlinepress.com/journals/gscarr

(REVIEW ARTICLE)

\title{
Ethics in clinical research
}

\author{
Nagla Hussein Mohamed Khalid * \\ Department of Radiological science, Faculty of Applied Medical Sciences, Najran University, KSA, P.O.Box1989 KSA- \\ Najran.
}

Publication history: Received on 21 October 2020; revised on 04 November 2020; accepted on 06 November 2020

Article DOI: https://doi.org/10.30574/gscarr.2020.5.2.0091

\begin{abstract}
Ethics in medical education research is associated with any research concerning human participants and including anthropological tissue conducted by supervising and scholars of the University. It is associated with the accountability of the researcher, to be honest, and privacy and confidentially and autonomy and respectfully to all participants who affected by their research studies. Objectives of the review: The motivation behind this report is to look at the ethical issues raised when investigating including human members. In addition, to demonstrate the important ethical consideration with academic medical research. Conclusion: Ethics of restorative research on human subjects should be clinically supported and deductively stable. Educated consent is a compulsory segment of any clinical research. Investigators are committed to configuration look into protocols that build up guidelines of logical respectability, safeguard ethical and authoritative issues of the human subjects, and follow the conventions for forthcoming survey by independent research morals boards of trustees.
\end{abstract}

Keywords: Ethics; Clinical research; Code of ethics; Humanities

\section{Introduction}

Ethics could be a systematic approach to understanding, analyzing and distinguish matters of right and wrong, smart and dangerous and admirable and deplorable as they associated with the successfulness of and relationship among sentient being. Ethics is an active process rather than statistical conditions when people are doing ethics they need to support the beliefs and assertion with sound reasoning. ${ }^{11]}$ Due to this conflict, research with human being field continues to be one of the most controversial topics in bioethics, despite ample government regulation, institutional oversight, and professional counsel. [2]

Realizing what comprises moral inquiry is vital for all individuals who direct research task or use and apply the outcomes from research discoveries. All scientists ought to be comfortable with the fundamental moral monetary standard and have avant-garde learning about arrangements and strategy intended to guarantee the security of research content and to avoid messy or flippant research since obliviousness of approaches intended to ensure inquire about subjects is not viewed as a practical reason for morally flawed activeness. In this way, the obligation Trygve Lie with the specialist to search out and completely comprehend the strategies and speculations intended to ensure upstanding test rehearses. ${ }^{[3]}$

Research ethics is most created as an idea in tonic research; however, the full general standards apply for all fields of research. Educated acquiescence and classification are critical for a sociological report as they are for clinical research. Despite the fact that interrogatory ethics is most created inside the setting of curative research, look into morals is of

\footnotetext{
* Corresponding author: Nagla Hussein Mohamed Khalid; Tel : 00966500554615; E-mail: najlabashab@yahoo.com Department of Radiological science, Faculty of Applied Medical Sciences, Najran University, KSA, P.0.Box1989 KSA-Najran. 
critical meaning for every logical space. Expert and scholastic affiliations have frequently given counseling archives and ethics codes.

Table 1 Declaration of code of ethics $\{4\}$

\begin{tabular}{|c|c|}
\hline Number & Code of ethics \\
\hline 1 & The research participants should intentionally approve to investigate interest. \\
\hline 2 & Research aims to add to the benefit of society. \\
\hline 3 & Research must be founded on sound hypothesis and earlier creature testing. \\
\hline 4 & $\begin{array}{l}\text { Research must maintain a strategic distance from purposeless physical and mental } \\
\text { suffering. }\end{array}$ \\
\hline 5 & $\begin{array}{l}\text { No investigation tasks can go ahead where genuine damage as well as death are potential } \\
\text { results. }\end{array}$ \\
\hline 6 & $\begin{array}{l}\text { The level of hazard taken with research participants can't exceed predicted advantages of } \\
\text { results. }\end{array}$ \\
\hline 7 & Appropriate environmental and protection for members is essential. \\
\hline 8 & Experiments can be directed just by scientifically qualified individuals. \\
\hline 9 & . Human subjects must be permitted to stop their interest whenever. \\
\hline 10 & $\begin{array}{l}\text { Researchers must be set up to end the investigation if there is cause to trust that } \\
\text { continuation will be hurtful or result in damage or death. }\end{array}$ \\
\hline
\end{tabular}

\section{Thought for research in participate}

Table 2 Ethical standards of research in the humanities are partitioned into the following regions

\begin{tabular}{|l|l|}
\hline Standard & Statements \\
\hline Informed & $\begin{array}{l}\text { Informed consent refers to an ethical and legal doctrine based on the reason that all } \\
\text { interference (diagnostic, therapeutic, preventive, or related to scientific subject area) in } \\
\text { the medical field should only be performed after a participant has been informed about } \\
\text { the intention, nature, consequences, and risks of the intervention and has freely } \\
\text { consented to it. [5] The essential focal point of approval should be on illuminating and } \\
\text { protect research subjects, through expose and talk of pertinent data, meaningful } \\
\text { endeavours to advance members' discernment, and by assuring that choices to take a } \\
\text { stake or to continue participating, constantly make wilfully. }\end{array}$ \\
\hline $\begin{array}{l}\text { Patient } \\
\text { information } \\
\text { sheet }\end{array}$ & $\begin{array}{l}\text { Patient selective information sheet specifying the following gradient of the study Title of } \\
\text { the inquiry projection, Invitation to participate in the research, Part, and import of } \\
\text { research, Time loyalty, Outcome of engagement, indication voluntary donation, } \\
\text { Endangerment involved, Cost and compensation and Anonymity and confidentiality }\end{array}$ \\
\hline Avoiding harm: & $\begin{array}{l}\text { An essential assignment of recorded and social research is to create data on the } \\
\text { inappropriate working of social foundation garment and issues with deference to the } \\
\text { usage of intensity Conceivable wrong coming about because of research can originate } \\
\text { from the gathering of information, the capacity of information and effect following the } \\
\text { distribution of work. However Direct or indirect coercion of population in the name of } \\
\text { research must be avoided under all situations. Coercion may include the exploitation of } \\
\text { vulnerable citizenry; taking undue reward of a participant, volunteer or any other } \\
\text { person; or the misuse of the authority and influence of the research[6] }\end{array}$ \\
\hline Confidentiality & $\begin{array}{l}\text { Confidentiality must be respected under all condition. Certification should be } \\
\text { safeguarded and viewed as a strictly common soldier in footing of the terminus ad quem }\end{array}$ \\
\hline
\end{tabular}




\begin{tabular}{|c|c|}
\hline & $\begin{array}{l}\text { facility by the inquiry projection. However, Confidentiality means value the } \\
\text { nondisclosure of certain information except to another authorized someone . } \\
\text { The conception of confidentiality applies that the knowledge an individual reveals to } \\
\text { knowledgeable is personal and has limits on however and once it are often disclosed to } \\
\text { a third party [7] }\end{array}$ \\
\hline Privacy & $\begin{array}{l}\text { Privacy is the calibre of being secluded from the presence or prospect of others. Privacy } \\
\text { in research refers to the right of a mortal to shuffling decisions concerning how much } \\
\text { information about their physical position, health, sociable network, and sentiment and } \\
\text { feelings will be shared with investigators [8]. Regard for the self-sufficiency of the } \\
\text { participant, whether the patient role or unpaid employee, need that the participant must } \\
\text { be treated as a unique human being person within the context of the use of his or her } \\
\text { residential district system. Exemption of choice must be safeguarded. Although Human } \\
\text { right-hand Respect for the staple right hand of the somebody as a human being as well } \\
\text { as the rights of mathematical group and community }\end{array}$ \\
\hline Communication: & $\begin{array}{l}\text { Clear and understandable verbal communicating is required, with information. } \\
\text { Emotional and cultural values should be considered }\end{array}$ \\
\hline $\begin{array}{l}\text { Respect and } \\
\text { responsibility }\end{array}$ & $\begin{array}{l}\text { Respect in research refers to an agreement for people and respect for verity. People have } \\
\text { the right to self-respect and privacy (informed consent and confidentiality). Respect for } \\
\text { truth implies probity and respect for the intellectual rights of others. All possible travail } \\
\text { should be directed to avoid piracy and clinching false conclusions by over and under } \\
\text { underscoring the result [9]. Responsibility of the human subject involves voluntary } \\
\text { informed consent, avoiding deception, reinforcement and inducements, privacy, and } \\
\text { revelation. Also, the researchers are responsible for maintaining the repute of } \\
\text { educational research by adhering to the highest standard of quality research. When } \\
\text { publication the research, investigators should disclose any competing or financial } \\
\text { interests. }\end{array}$ \\
\hline
\end{tabular}

Many trust that inform consent makes clinical research moral. Be that as it may, inform consent is neither important nor adequate for moral clinical research. Drawing on the essential theories fundamental real codes, presentations, and different reports pertinent to look into with human subjects, 7 necessities can be recommended that methodically clarify a reasonable structure for assessing the morals of clinical research considers:

Table 3 Issues that makes clinical research ethics [10]

\begin{tabular}{|c|c|}
\hline Number & Issues \\
\hline 1 & esteem-upgrades of wellbeing or information must be gotten from the examination \\
\hline 2 & logical legitimacy—the exploration must be methodologically thorough; \\
\hline 3 & $\begin{array}{l}\text { reasonable subject determination-logical goals, not helplessness or benefit, and the potential } \\
\text { for and dissemination of dangers and advantages, ought to decide networks chose as study } \\
\text { destinations and the consideration criteria for individual subjects. }\end{array}$ \\
\hline 4 & $\begin{array}{l}\text { great hazard advantage proportion-inside the setting of standard clinical practice and the } \\
\text { exploration convention, dangers must be limited, potential advantages improved, and the } \\
\text { potential advantages to people and learning picked up for society must exceed the dangers }\end{array}$ \\
\hline 5 & free audit - unaffiliated people must survey the examination and affirm, revise, or end it \\
\hline 6 & $\begin{array}{l}\text { educated assent-people ought to be educated about the exploration and give their wilful } \\
\text { assent }\end{array}$ \\
\hline 7 & $\begin{array}{l}\text { Regard for selected subjects-subjects ought to have their security ensured, the chance to pull } \\
\text { back, and their prosperity observed. Satisfying each of the }\end{array}$ \\
\hline
\end{tabular}


Prerequisites is fundamental and adequate to make clinical research moral. These prerequisites are all- inclusive, in spite of the fact that they should be adjusted to the wellbeing, monetary, social, and mechanical conditions in which clinical research is conducted

\subsection{Role of Research ethics committee in clinical researches}

Research ethics committee (also known as ethical review board (ERB), ethical review committee (ERC), human research ethics committee (HREC), institutional review board (IRB)): Group of individuals who undertake the ethical review of analysis protocols involving humans, applying united moral principles. The main responsibility of \{an analysis a search an enquiry a quest a pursuit a probe an exploration a groundwork a hunt research a look\} committee is to shield potential participants within the research, but it must also take into account potential risks and benefit ts for the community in which the research will be carried out. Its final goal is to market high moral standards in analysis for health. [11]

Research ethics committees exist is almost every country and operate under legal/regulatory authority. In the US, they are mandated by federal regulations that have the force of law but are appointed by and report to a research institution, such as a university, hospital, or research institute. There also are free standing for profit and not-for-profit IRBs. The Regulations mandate structure, composition/membership, meeting requirements, standard operating procedures and record keeping requirements. ${ }^{[12]}$

Composition of IRBs/RECs is diverse. Generally, appointments include men and women from various scientific and nonscientific fields, members who are independent of the institution(s) conducting the research or the organization(s) sponsoring it, and people who understand the research subjects and their environments. Consultants is also known as upon PRN, particularly if the research involves an area in which few or no regular members have expertise. Anyone with conflicts of interest should disclose those interest(s) and not participate in higher cognitive process. Although scientists, advocates, institutional officers and ethicists all have views and interests, it's assumed decisions. [12]

All research involving humans, whether patients or healthy volunteers, must be referred to a Research Ethics Committee. Sometimes class approval may be given in advance to applications for minor research, or a series of studies of a particular type carried out as a regular feature of a research or training programmer. Even in these circumstances, the Committee will wish to be informed of each individual study by title at least [7]

The fundamental aims of research moral board of trustees is the accompanying the goals of Research Ethics Committees are the accompanying: to keep up moral models of training in research; to shield inquire about members and agents from damage or misuse, to protect the examination participant's rights, which take inclination over society's rights; and to give consolation to society this this is wearing..

The Research Ethics Committee should make sure that the capable investigator is fittingly qualified and experienced.

The Research Ethics Committee ought to likewise guarantee that: ${ }^{[13,14]}$

\begin{tabular}{|l|l|}
\hline No & Aims \\
\hline 1 & $\begin{array}{l}\text { Adequate preliminary literature has been consulted and experimental studies have been } \\
\text { undertaken }\end{array}$ \\
\hline 2 & $\begin{array}{l}\text { Every reasonable effort has been made to inform prospective participants of the objectives } \\
\text { and consequences of their involvement and particularly of identifiable risks and inconvenience. } \\
\text { Informed consent should be obtained }\end{array}$ \\
\hline 3 & $\begin{array}{l}\text { Any arrangement to delegate consent has adequate justification, and that appropriate } \\
\text { safeguards have been instituted to ensure that the rights of participants will not be abused }\end{array}$ \\
\hline 4 & $\begin{array}{l}\text { Appropriate measures have been adopted to ensure the confidentiality of data generated in the } \\
\text { course of research, through the use of coding or anonymity of participants, for example }\end{array}$ \\
\hline
\end{tabular}


Every effort has been made to ensure that participants have an opportunity to comment on and, if they wish, to decline to participate, or to withdraw from a research project easily - without having to give a reason, and without any adverse consequence

\section{Research ethics regulation}

In recent times, there has been increasing regulation of social and educational research. Initially, this took the form of ethical codes established by professional associations, with universities and other research organizations sometimes requiring their members to adhere to these codes. More recently, ethics committees have been established in universities, and in other organizations, or the remit of existing committees has been extended to include social and educational research. Moreover, there has been a tendency for the operation of these committees to be modelled on the regulation of medical research, though there have also been recent attempts to make their approach more appropriate. This increased regulation is controversial, not least because of the complexities surrounding the ethical judgments involved in research. There are also questions to be raised about the legitimacy of ethics committees in principle, and about the effects of their operation: do they encourage more and better dialogue about ethical matters; or do they, in effect, falsely reduce ethical consideration to a matter of compliance with a code or to the use of a tool like a consent form? There is now a considerable literature on ethical regulation. [15]

\subsection{Researches ethics regulation and quid lines in Arab region}

Due to the increasing number of research and clinical trials being performed in the Arab region, regional ethicists have well-defined the many ethical issues involving human participants in research. These issues have been brought to the attention of officials of national governments, universities, research centers, and other stakeholders. The use of international codes of ethics to guide local research reflects the initial response. But the local application of international guidelines fails to account for cultural, economic, social, religious, and political aspects that often influence research practice. Indeed, in a study conducted among members of RECs in Egypt, 92\% ranked that the lack of appropriate national guidelines represents a major challenge for RECs and investigators.[16] However Alarmed et al 2012 explore Thirteen Arab countries in the Middle East were explored for available national codes, regulations, and guidelines concerning research ethics, and 10 documents from eight countries were found. And he reported that Efforts have been made to regulate research ethics in some countries in the Middle East. These efforts are often seen within the new rules that contain all or most of the protections mentioned within the international pointers associated with analysis ethics, like the ICH-GCP, the CIOMS guidelines, and the Declaration of Helsinki .

Table 4 Research ethics regulation and quid lines in Arab country 2015 [18]

\begin{tabular}{|c|c|c|c|}
\hline Country & Name of issue & Date of issue & The issuing organization \\
\hline Sudan & $\begin{array}{l}\text { National guidelines for Ethical } \\
\text { Conduct of Research Involving } \\
\text { Human Subjects }\end{array}$ & 2008 & National Ministry of Health \\
\hline Saudi Arabia & $\begin{array}{l}\text { The low of ethics of research on } \\
\text { living creatures \& SFDA clinical } \\
\text { trial requirements }\end{array}$ & $\begin{array}{l}\text { 2010-2011 } \\
\text { Reviewed } 2015\end{array}$ & Council of Ministry of health \\
\hline UAE & $\begin{array}{l}10 \text { (Federal law No concerning } \\
\text { medical liability (2008) The } \\
\text { cabinet decision No. (33) of } 2009\end{array}$ & $2008-2009$ & Ministry of health \\
\hline Qatar & $\begin{array}{l}\text { Guidelines regulations and } \\
\text { policies for research }\end{array}$ & 2009 & Ministry of health \\
\hline Kuwait & $\begin{array}{l}\text { Ethical guidelines for biomedical } \\
\text { research }\end{array}$ & 2001 & $\begin{array}{l}\text { Kuwait Institute for Medical } \\
\text { Specialization }\end{array}$ \\
\hline Bahrain & $\begin{array}{l}\text { ethical guidelines for health } \\
\text { research (draft) }\end{array}$ & 2009 & Ministry of health \\
\hline Jordan & Clinical Studies Law & 2001 & Prime Minister's Council \\
\hline
\end{tabular}




\begin{tabular}{|l|l|l|l|}
\hline Morocco & $\begin{array}{l}\text { Protection of persons } \\
\text { participating in biomedical } \\
\text { research }\end{array}$ & 2015 & Parliament \\
\hline
\end{tabular}

Specifically, these efforts are often seen within the Qatari pointers and also the Saudi "Clinical Trial demand Guidelines" crafted by the SFDA, each of that contain the most range of protections-19 and 15 respectively .However, the Arab geographic region countries were at very different levels with respect to the event of analysis ethics guidelines; most of the GCC (The Cooperation Council for the Arab States of The Gulf) made advanced steps in this regard compared with non-GCC countries [17]

Silverman 2017 in his review of the existing regulations and guidelines for research in the Arab countries reported That several countries have issued regulations codified in the form of a law while others have guidelines; several countries do not have special guidelines regarding research, but the ethics of research is mentioned in other documents, such as the code of ethics in Egypt, and in Lebanon; other countries such as Syria and Iraq use the international guidelines (e.g., Helsinki Declaration or CIOMS); and finally, other countries make no references to clinical research (Palestine and Yemen). Our analysis of the existing national regulations and guidelines shown in Table 1 reveal that all documents include independent review of research and the securing the informed consent. However, there are important missing requirements in several of these documents, such as social value in the Emirati, Qatari and Kuwaiti guidelines [18]

\section{Conclusion}

Ethics of restorative research on human subjects should be clinically supported and deductively stable. Educated consent is a compulsory segment of any clinical research. Investigators are committed to configuration look into protocols that build up guidelines of logical respectability, safeguard ethical and authoritative issues of the human subjects, and follow the conventions for forthcoming survey by independent research morals boards of trustees.

\section{Compliance with ethical standards}

\section{Acknowledgments}

The author thanks all who contributed to this study.

\section{Disclosure of conflict of interest}

The author declare no conflict of interest.

\section{References}

[1] Karen .L. rich Nursing Ethics: Across the Curriculum and Into Practice, Third Edition; copyright Jones and Bartlett Learning, 2018.

[2] David B. Resnik: The Ethics of Research with Human Subjects, The Ethics of Research with Human Subjects: Springer International Publishing AG p13 2018.

[3] Saif M world medical declaration association of helisinki; ethical principles for medical research involving human subject. J AM med assoc. 2000; 284:3043-5.

[4] Utley GJAER. The Nazi doctors and the Nuremberg Code: humanrights in human experimentation: human rights in human experi-mentation. Oxford University Press; 1992.

[5] Glickman SW, McHutchison JG, Peterson ED, Cairns CB, Harring-ton RA, Califf RM, et al. Ethical and scientific implications ofthe globalization of clinical research. N Engl J Med 2009; 360(8):816-23.

[6] Gilman RH, Gracia HH. Ethics review procedures for research in developing countries: a basic presumption of guilt. Canadian Medical Association Journal 2004; 171(3): 248-249.

[7] Mielke HW. Research ethics in pediatric environmental health:lessons from lead. Neurotoxicol Teratol 2002; 24(4):467-9.[33] Woodward Z, Argent VP. Patient confidentiality. Curr ObstetGynaecol 2005; 15(3):211-4.

[8] Fisher CB. Privacy and ethics in pediatric environmental healthresearch-part I: genetic and prenatal testing. Environ Health Per-spect 2006; 114(10):1617. 
[9] Tauber AI. Patient autonomy and the ethics of responsibility. The MITPress; 2005.

[10] Md.Ashraf ali: what makes multinational clinical research ethical \& how to minimize possible exploitation in host country? Bangladesh journal of bioethics 2011; 2(2): 20-23.

[11] World Health Organization Research ethics committees Basic concepts for capacity-building: 2009 ; ISBN 97892 41598002.

[12] https://obssr.od.nih.gov/wp-content/uploads/2016/05/Ethical-Challenges.pdf e- sourse behavior and social science researches

[13] Cowell HR. Ethical responsibilities of editors, reviewers and authors. Clin Ortho.2000; 378: 05218.

[14] Kottow MH. Who is my brother's keeper? Journal Medical Ethics 2002; 28(1):24-27.

[15] Hammersley, M. and Traianou, A. Ethics and Educational Research, British Educational Research Association online resource. Available on-line at:www.learnersfirst.net/private/wp-content/uploads/Ethics-and-EducationalResearch. 2012.

[16] Sleem.H.S ElKammary, and HJ. Silverman. Identification structures, processes, resources and needs of Research ethics committee in Egypt. BMC medical ethics2010: 11.12.

[17] Ghiath Alahmad, Mohammad Al-Jumah and Kris Dierickx: 2012 licensee BioMed Central Ltd. 2012 licensee BioMed Central Ltd. 2012.

[18] Henry Silverman: Research Ethics in the Arab Region: Springer International Publishing AG 2017 Springer, Cham DOI https://doi-org.sdl.idm.oclc.org/10.1007/978-3-319-65266-5 